and prolonged rehabilitation. The estimated overall savings on accident costs from the first year of seat belt legislation is of the order of $£ 120$ million-enough to finance the running of four whole health districts for one year. ${ }^{7}$

We need to remember, however, that wearing seat belts by all occupants of motorcars is only a form of secondary prevention in that it reduces the severity of injury after the accident has happened. More attention needs to be paid to primary prevention-in the form of improving the behaviour of drivers and especially in discouraging them from drinking and driving.

Members of Parliament welcome expert advice and informed comment, especially when these are based on sound evidence. The doctors' lobby was an important factor in the first stage of seat belt legislation. Should the BMA now adopt the next step as part of its policy? And should doctors lobby their own local members of Parliament to prompt them to support the early day motion?

J G AvERY

District Medical Officer,

South Warwickshire Health Authority,

Warwick CV34 4DE

${ }_{1}$ Department of Transport. Road accidents and casualties in Great Britain. Bulletin No STC 4 (84) 1. (Also reported in Hansard 1984 Jan 16;446: cols 836-9. (No 56.))

2 Bérard-Andersen $\mathrm{K}$. Use and effects of seat belts in 21 countries. Oslo: Institute of Transport Economics, 1978.

${ }^{4}$ Griffiths DK, Hayes HRM, Gloyns PF, Rattenbury SJ, Mackay GM. Car occupant fatalities and the effects of future safety legislation. In: Proceedings of the 20th STAPP car crash conference, Dearborn, Michigan, 1976. Warrendale, New York: Society of Automotive Engineers, 1976. (SAE paper 7670811.)

${ }^{5}$ Boughton CJ, Johnson IR. The effects of radio and press publicity on the carriage of children in cars. In: 1979 SAE congress and exposition, Detroit, USA. Melbourne, Australia : Office of Road Safety, Department of Transport, 1977. (Mimeograph.)

${ }^{6}$ Reisinger KS, Williams AF. Evaluation of programs designed to increase the protection of infants in cars. Pediatrics 1978;62:280-7.

${ }^{7}$ Anonymous. Rear seat belts. Br Med $\mathcal{F} 1984$;288:409.

\section{Mortality and morbidity among the old}

Today there are two and a half times as many people aged over 85 as there were 30 years ago. The size of this age group will continue to increase throughout the rest of this century whether or not death rates among the very old continue to fall. Those aged 85 spend on average 12 days a year in hospital, compared with under one day a year for nearly all those aged under 55 and just over two days a year for those aged 65 . Providers of health and social services expect that this increase in the number of very old people will place further pressure on already inadequate resources. ${ }^{1}$

In 1980 Fries presented a more optimistic view of the future. ${ }^{2} \mathrm{He}$ argued that the upper limit to the human life span was biologically fixed at about 115 and that the average life expectancy was unlikely to exceed 85 . Advances in the prevention and treatment of disease, particularly through changes in health related behaviour, would delay the onset of morbidity but would not affect the length of life. The number of very old people would stop increasing, morbidity would be compressed into a shorter period before death, and the need for medical resources would be reduced. Death would result from the biological process of aging rather than from a specific disease. In this society, which Fries thought was fast approaching, the survival curve would assume a "rectangular" shape. A near horizontal line depicting the low mortality up to about 85 would be followed by a sharp drop at the age of "natural death."

The concept of a fixed limit to the human life span, central to the Fries hypothesis, is not new. ${ }^{3}$ To support this, Fries cited Hayflick's demonstration of the finite capacity of certain cultured cells for in vitro replication. ${ }^{4}$ Hayflick suggested that this limit was not reached by cells in vivo, but that other functional losses occurred before replication stopped.

Fries's reliance on Hayflick's work, and the inferences that he draws from it, have been criticised. ${ }^{5}$ Fries noted that there had been no increase in the number of centenarians and used this as further support for his case. He also argued that aging is associated with progressive loss of organ reserve, eventually resulting in death, and that the Gompertz law of exponential increases in mortality with age was the statistical model which best reflected this biological process. ${ }^{6}$ Nevertheless, the Registrar General of England and Wales has recently shown that those born in 1880 were four times as likely to reach the age of 100 as those born just 30 years earlier, and that the Gompertz law does not adequately describe mortality patterns at advanced ages. ${ }^{7}$

The evidence in favour of a fixed limit to the life span is far from conclusive, but even if the hypothesis is accepted it is not clear how relevant it is to issues of immediate concern. Benjamin pointed out that no one has yet lived in an environment allowing aging unaffected by diseases of external origin. ${ }^{8}$ Persisting mortality differentials suggest plenty of scope for further improvements and, although the incidence of some chronic diseases seems to be falling, ${ }^{9}$ others are on the increase. Successes in disease prevention may yet turn out to affect biological indices of aging: smoking, for example, seems to be associated with an earlier age of the menopause. ${ }^{10}$

Many of Fries's predictions rely not just on an upper limit to the life span but also on an "ideal average life span" of 85 . To arrive at this figure Fries made a calculation from past trends in mortality which entails assuming that, given an overall level of mortality, there is a fixed relation between death rates at different ages. He also had to assume that at some stage deaths between birth and the age of 65 are eradicated. The first of these assumptions is known to be false $\mathrm{e}^{11}$; the second, most would agree, is distinctly improbable.

Fries is correct that falls in mortality have been proportionately greatest among the young and have progressively declined with age. This does not mean that there have been no changes in mortality at older ages. Investigation of mortality trends among the very old is hampered by problems of data. In England and Wales inflation of age at a census was a serious problem until well into this century ${ }^{12}$; problems at extreme ages still persist. ${ }^{7}$ Ages recorded on death certificates are generally more accurate, ${ }^{13}$ resulting in errors in the calculation of death rates due to the incompatibility of numerator and denominator. Investigators who have devised methods of dealing with these problems have all reached the same conclusionnamely, that there has been a real and significant fall in mortality even among those aged over 85 . In America the recent percentage falls in mortality in this age group exceed those in all other age groups over 25.14-16 Manton found no indication that mortality rates among the very old were reaching a ceiling. ${ }^{17}$

The figure shows percentage changes in death rates at various ages in England and Wales since 1891-1900. There have been fairly sizable falls in the mortality of the oldest age groups, and these show no sign of levelling off. Between 
1970-2 and 1978-80 life expectancy at age 85 increased by about six months to $4 \cdot 6$ years for men and 5.6 years for women. Even centenarians now have a greater than $50 \%$ chance of surviving from one year to the next.?

The optimistic predictions that Fries made about morbidity rested on assumptions about mortality not supported by the

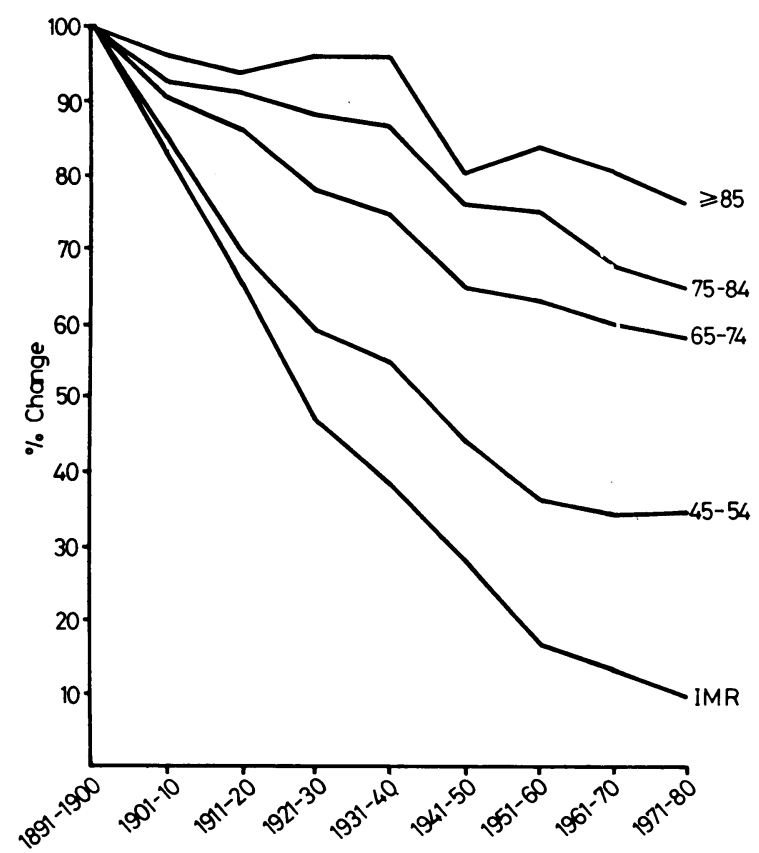

Percentage changes in age specific death rates in selected age groups in England and Wales during 1891-1900 to 1971-80. (Figure for $1891-1900$ taken as $100 \%$. IMR = Infant mortality rate.)

data; nevertheless, they have attracted particular attention. ${ }^{61819}$ Fries argued that the relation between morbidity and mortality is changing in a favourable direction but offered no evidence in support of this contention.

Gruenberg suggested that, on the contrary, we were now keeping people with chronic conditions, including mental disorders, alive longer. ${ }^{20}$ Manton also concluded that the duration of chronic conditions was increasing, although unlike Gruenberg he attributed this to a reduced rate in the progression of some diseases due to innovations such as the control of hypertension. ${ }^{17}$ Several studies have shown an increase in the life expectancy of those with dementia. ${ }^{21-23}$ This alone should temper optimism.

Changes in death rates at advanced ages do not exert a major influence on the age structure of the population as a whole or on the calculation of life expectancy at birth. ${ }^{24} 25$ They do affect, however, the size and structure of the elderly population itself. $^{26}$ Mortality among the old seems to be falling at a faster rather than a slower rate than before and there is no sign of a "compression of morbidity." Old people may die from diseases that do not kill those in middle age; that is not the same as dying a "natural death."27

Predictions based on the experiences of current generations of very old people should be made with care, as cohort differences are likely to be important. Nevertheless, we may be certain that now and in the immediate future more rather than fewer resources will be needed to cope with growing numbers of very old people.

EMILY GRUNDY

Research Fellow,

Social Statistics Research Unit,

Department of Mathematics,

City University,

London EC1V OHB

1 Evans JG. Demography and resources. Medicine (Oxford) 1978;3rd series: $12-4$.

${ }^{2}$ Fries JF. Aging, natural death, and the compression of morbidity. $N$ Engl f Med 1980;303:130-5.

${ }^{3}$ Bourgeois-Pichat J. Essai sur la mortalité biologique de l'homme. Population 1952;7:381-94.

${ }^{4}$ Hayflick L. Current theories of biological aging. Fed Proc 1975;34:9-13.

${ }^{5}$ Schneider EL, Brody JA. Aging, natural death, and the compression of morbidity: another view. $N$ Engl f Med 1983;309:854-6.

${ }^{6}$ Gompertz B. On the nature of the function expressive of the law of human mortality. Philosophical Transactions of the Royal Society of London 1825;1:513-85.

7 Thatcher AR. Centenarians. Population Trends 1981;No 25:11-4.

${ }^{8}$ Benjamin B. The span of life. Fournal of the Institute of Actuaries 1982; 109:319-57.

${ }^{9}$ Dwyer T, Hetzel BS. A comparison of trends of coronary heart disease mortality in Australia, USA and England and Wales with reference to three major risk factors-hypertension, cigarette smoking and diet. Int $\mathcal{F}$ Epidemiol 1980;9:65-71.

10 Willett W, Stampfer MJ, Bain C, et al. Cigarette smoking, relative weight, and menopause. Am $\mathcal{F}$ Epidemiol 1983;117:651-8.

11 Preston SH. Mortality patterns in national populations. New York: Academic Press, 1976.

12 Lee R, Lam D. Age distribution adjustments for English censuses, 1821 to 1931. Population Studies 1983;37:445-64.

${ }^{13}$ Humphrey FT. Mortality at the oldest ages. Fournal of the Institute of Actuaries 1970;96:105-19.

14 Depois F. La mortalité des grands vieillards. Population 1973;28:755-92.

${ }^{15}$ Rosenwaike I, Yaffe N, Sagi PC. The recent decline in mortality of the extreme aged. An analysis of statistical data. Am $\mathcal{F}$ Public Health 1980; 70:1074-80.

${ }^{16}$ Rosenwaike I. A note on new estimates of the mortality of the extreme aged. Demography $1981 ; 18: 257-66$.

17 Manton KG. Changing concepts of morbidity and mortality in the elderly population. Milbank Mem Fund $Q$ 1982;60:183-244.

18 Brody JA. Life expectancy and the health of older persons. $f$ Am Geriatr Soc $1982 ; 30: 681-3$.

${ }^{19}$ Bromley D, Isaacs A, Bytheway B. Review symposium, ageing and the rectangular curve. Ageing and Society 1982;2:283-392.

${ }^{20}$ Gruenberg EM. The failures of success. Milbank Mem Fund $Q$ 1977;55: 3-24.

${ }^{21}$ Christie AB. Changing patterns in mental illness in the elderly. $\mathrm{Br} \mathfrak{F}$ Psychiatry 1982;140:154-9.

22 Blessed G, Wilson ID. The contemporary natural history of mental disorder in old age. Br 7 Psychiatry 1982;141:59-67.

${ }^{23}$ Hagnell O, Lanke J, Rorsman B, Ojesjö L. Does the incidence of age psychosis decrease? A prospective, longitudinal study of a complete population investigated during the 25-year period 1947-1972: the Lundby study. Neuropsychobiology 1981;7:201-11.

${ }^{24}$ Keyfitz N. Improving life expectancy: an uphill road ahead. Am $\mathcal{F}$ Public Health 1978;68:954-6.

25 Tsai SP, Lee ES, Hardy RJ. The effect of a reduction in leading causes of death: potential gains in life expectancy. Am $\mathcal{f}$ Public Health 1978; 68:966-71.

${ }^{26}$ Benjamin B, Overton E. Prospects for mortality decline in England and Wales. Population Trends $1981 ; 23: 22-8$.

${ }^{27}$ Kohn RR. Causes of death in very old people. FAMA 1982;247:2793-7. 